that fall are like blood. The phenommon, which is known by the name of blood rain, is attributed to dust from the Sahara Desert, carried here by the wind." And the Rome correspondent of the Auency on the same date says: "The phenomena reported from Sicily have also been observed in Southern Italy. The sky here has a yellow tint, and a violent sirocco is sweeping over the city. At Naples showers of sand have fallen, and the phenomenon of the Fata Morgana has been observed, the sky being of a deep red colour."

Later reports from Algiers describe the same occurrence in North Africa, and the explanation suggested is no doubt correct. It is simply a case of fine sand raised to a great height by one of the "dust devils" or whirlwinds of the Sahara, and carried by the movement of the upper air to a considerable distance before the particles, resisted in their fall by the friction of the air, have succeeded in reaching the ground. If rain happens to fall through such a cloud of suspended dust it naturally carries down a good deal of the material with it, and leaves red stains on drying up. If there is no rain, the fall of dry dust takes place all the same, and this effect is well known at sea in the trade-wind belt west of the Sahara.

It must be remembered that another kind of "blood rain," even more effective in appealing to the fears of the ignorant and superstitious, owes its alarming tint to the presence of minute organisms similar to those of red snow.

Dust rains of one kind or another are fairly frequent. Those of "sulphur" have been traced to the pollen blown abroad from conifers in the spring, and those of "ink," unhappily commoner in this country, to the catching up of smoke from manufacturing districts. Such a black rain, accompanied by intense darkness, fell over nearly 500 square miles in the north of Ireland in February 1898 during a spell of north-easterly wind, while in May 18c9 a similar phenomenon was reported over an equal area of central and south-western England.

The precise atmospheric conditions necessary for the raising of dust or smoke into the upper parts of the atmosphere, and for the concentration and descent over special areas, is not yet fully understood; but the careful meteorological observations now made in many parts of Italy may be expected to throw some light on the general phenomenon when dealing with the recent occurrence.

\section{DR. G. M. DAWŚNON, C.M.G., F.R.S.}

GEOLOGICAL science, and Canada in particular, have suffered an irreparable loss in the death of George Mercer Dawson, C.M.G., LL.D., F.R.S., the director of the Geological Survey of that Dominion. He was born at Pictou, Nova Scotia, on August I, I 849 , and was the eldest surviving son of the late Sir John William Dawson, whose death was recorded in NATURE for November 23, 1899.

After studying at the McGill Lniversity in Montreal, he came to London and entered the Royal School of Mines in 1869. Here he gained the Duke of Cornwall's scholarship and the Edward Forbes and Murchison medals, thus passing with distinction as an Associate of the School. The training which he received in biology, as well as in geology and mining, was of essential service in his after career.

Having returned to Canada, he was in 1873 appointed geologist and botanist to the North American Boundary Commission, and two years later he joined the staff of the Geological Survey of Canada, becoming assistant director in 1883 and director in 1895 .

No. 1637 , vOL. 63 ]
For nearly thirty years he was thus actively engaged in field-work, gaining a broad and firm grasp of the leading features in the geology of Canada. If, as he himself remarked, much of his work was "of an exploratory character, and only occasionally, and then to a limited extent, precise or finished," it has been none the less important in advancing the science of geology and in furthering the development of the mineral resources of the Dominion. Far better equipped as a pioneer than was possible in the early days of geology, and keen in the examination of fresh ground, his enthusiasm was tempered only by the reluctance in leaving unsolved those problems which required further detailed study. In spite of constitutional infirmity, he possessed a marvellous amount of energy, while as a companion and leader he gained the confidence and affection of all who had the privilege of working with him.

$\mathrm{H}$ is contributions to science, though mainly geological, were imbued with a general knowledge of natural history, and included observations on such subjects as seals, locusts and freshwater sponges. In geology he dealt at times with all the great formations, with volcanic rocks, with changes in the level of land, and with fluctuations of the great $A$ merican lakes. In one of his earlier papers, communicated to the (ieological Society of London, he described the glacial phenomena of the central regions of North America, and attributed the deposits of the great plain to the action of floating ice. In later papers he gave accounts of the remarkable evidences of glaciation in British Columbia, and of the shore-lines and terraces which extend from the present sea-level up to a height of more than 5000 feet. He then maintained the marine origin of the drifts of the western plains, but stated his opinion without dogmatism, or, as he puts it (in the British Association Handbook of Canada), "under all reserve and subject to further inquiry."

Many of his geological observations were embodied in his official reports, commencing with a general description of the Tertiary Lignite formation which overlaps the Cretaceous strata of the Red River - a report prepared for the British North American Boundary Commission. On the Geological Survey his work lay principally in British Columbia and the North-IVest Territory. The economic resources necessarily occupied much attention, and the mines and minerals, as well as the more purely scientific problems, were investigated as fully as possible in Vancouver Island, Queen Charlotte's Island, the Yukon territory, and in all parts of British Columbia. He contributed also to journals and transactions of societies in the United States as well as in Canada.

In later years his time was so largely occupied with administrative work, and in the preparation of his annual reports of the progress of the Geological Survey in Canada, that he had little time for recreation. The full value of his work has hardly as yet been appreciated, but there is no doubt that his name will stand in the forefront among Canadian geologists. It is already written permanently in Dawson city, of gold-bearing fame, in recognition of his able researches in that region.

In 1891 he was elected a Fellow of the Royal Society of London, and in the same year he was appointed one of H.M. Behring Sea Commissioners. During the inquiry connected with this Commission he made personal observations on the natural history of seals, and his services were officially recognised by his being made C.M G. In 1891 also he was awarded the Bigsby Medal by the Council of the Geological Society of London, in appreciation of the value of his researches into the geological structure of Canada. In 1893 he was elected president of the Royal Society of Canada, and in 1896 he was chosen president of Section $\mathrm{C}$ at the Toronto meeting of the British Association.

He died on March 2 after a brief illness. 